\title{
Deprivation Counts: An Assessment of Energy Poverty in Pakistan
}

\author{
Rafat Mahmood* and Anwar Shah**
}

\begin{abstract}
This paper examines the energy-poverty nexus in Pakistan at the national and provincial level, using the multidimensional energy poverty index. Based on data from the Pakistan Social and Living Standards Measurement Survey for 2010/11, we find that the average household in Pakistan is 26.4 percent energypoor. The study shows that the incidence of energy poverty is higher in rural areas than in urban areas, with a similar trend at the provincial level. A comparison with findings based on data from 2008/09 shows a slight decrease in energy poverty at the national level.
\end{abstract}

Keywords: energy, poverty, households, Pakistan.

JEL classification: Q01.

\section{Introduction}

The notion of development goes hand in hand with the concept of sustainability: the use of resources for development by one generation such that it does not encroach on the prospects of the next (World Commission on Environment and Development, 1987). Munasinghe (1992) refers to this as 'sustainomics' and points out that sustainability in development must take into account three key perspectives: economic, social and environmental. Energy, as a building block of development, cuts across all three aspects (Goldemberg \& Johansson, 1995). Not only is it an input to the production function, necessary for economic growth ( $\mathrm{Hu} \& \mathrm{Hu}, 2013)$, but it is also a basic human need (Bravo et al., 1983) and essential for maintaining a minimum standard of living. Accordingly, those Millennium Development Goals (MDGs) that did not incorporate energy use were revisited - a country's ability to meet its energy requirements was seen as a prerequisite for achieving the MDGs (World Bank, 2002).

\footnotetext{
* Staff Economist, Pakistan Institute of Development Economics, Islamabad, Pakistan.

** Assistant Professor, Quaid-i-Azam University, Islamabad, Pakistan.
} 
A number of studies examine the relationship between energy and development at the household level. The use of modern cooking fuels (gas and electricity) is associated with better health, particularly among women and children, and a lower burden of disease (van der Klaauw \& Wang, 2003; Smith, Mehta \& Maeusezahl-Feuz, 2004). It also spares household members from having to collect traditional fuels such as wood or dung, giving them more time to spend on productive activities that lead to income generation, education and empowerment (United Nations Millennium Project 2005; United Nations Development Programme, 2000; Schultz, 1990). Similarly, the use of modern fuels to provide light plays a positive role in promoting education, health and communication (Fitzgerald, Barnes \& McGranahan, 1990; Department for International Development, 2002). Finally, modern energy sources improve environmental sustainability by reducing deforestation and enhancing energy efficiency (Leach and Mearns, 1988; Sarin, 1991).

The relationship between energy and development implies that it is important to track people's energy profiles across different dimensions and over time. This makes it possible to monitor changes in energy use and assess policy effectiveness. The multidimensional nature of the energy sector calls for indicators that can gauge overall progress but also make temporal and spatial comparisons. For a developing country such as Pakistan, where per capita energy consumption is far below that of comparable countries, it is necessary to assess the current situation and identify which areas need priority, ${ }^{1}$ given that Awan, Sher and Abbas (2013) have observed alarming levels of energy deprivation in the country.

This study employs a measure of energy poverty that takes into account a range of dimensions and has been adapted to suit Pakistan's case. We focus on energy deprivation rather than access to energy and estimate energy poverty both at the national and provincial levels as well as in rural and urban areas for the period 2008/09 to 2010/11. Section 2 looks at the literature on measures of energy poverty. Section 3 describes the study's methodology. Section 4 presents our results, accompanied by a discussion. Section 5 concludes the study.

\footnotetext{
${ }^{1}$ Pakistan's per capita energy use was $482 \mathrm{~kg}$ of oil-equivalent in 2011 compared to India (614 kg of oil-equivalent), Indonesia (857 $\mathrm{kg}$ of oil-equivalent) and $\operatorname{Iran}(2,813 \mathrm{~kg}$ of oil-equivalent) (International Energy Agency Statistics).
} 


\section{Measures of Energy Poverty}

Nussbaumer, Bazilian and Modi (2012) classify measures of poverty and development as (i) single indicators (such as the world poverty line), (ii) sets of individual indicators (such as the MDG indicators and energy indicators of sustainable development) or (iii) composite indices (such as the human development index and energy for development index). While single indicators generally fail to capture all dimensions of an issue as broad as energy poverty, sets of indicators lack insight into the overall state of affairs. Composite indices are thus more valuable in that they reflect multiple facets of a problem without losing the overall picture. Developing a representative composite index is, however, not easy: the more difficult it is to define and measure a problem, the less definitive its composite index is likely to be.

While some measures of energy poverty assume that income or general poverty necessarily begets energy poverty (Foster, Tre \& Wodon, 2000), the two are not always highly correlated (Pachauri \& Spreng, 2004; Pachauri et al., 2004). Other studies have, therefore, defined a separate poverty line for energy. For example, Barnes, Khandker and Samad (2011) define the level of energy demand that remains invariant to income as the minimum energy needed to subsist. However, this income-invariant property of energy demand is hard to imagine, even with respect to lowerincome households.

Pachauri et al. (2004) conduct a two-dimensional analysis of energy poverty that accounts for access to certain modes of energy and levels of consumption, but this approach is still too narrow. The International Atomic Energy Agency (2005) has devised an energy development indexon the lines of the human development index - that includes four dimensions of access to energy and allows cross-country comparisons. At the national level, however, the index loses its specificity with regard to energy inequality within a country and the percentage of people deemed energy-poor.

Comparing intra-country energy poverty in Punjab, Mirza and Szirmai (2010) define the energy poverty index as the arithmetic mean of the energy inconvenience and energy shortfall indices. They find that 91.7 percent of rural households in Punjab are extremely energy-poor. The wider applicability of this measure, however, requires more data, which is costly to collect. 
A simpler, more comprehensive index that builds on the available data and is used to make international comparisons is the multidimensional energy poverty index (MEPI) developed by Nussbaumer et al. (2012). It captures five dimensions of energy deprivation using six indicators: modern cooking fuel, lighting, services provided by household appliances, entertainment/education and communication. A household is thus considered energy-poor if its MEPI exceeds an acceptable minimum level of deprivation.

Using the Demographic and Health Survey dataset for 2006/07, Nussbaumer et al. (2013) show that Pakistan's MEPI is 0.45 on a scale of 0 to 1 . They calculate an energy poverty headcount of 0.69 and deprivation intensity of 0.66 . However, the data available does not allow for temporal and provincial comparisons of energy poverty in this case. Awan et al. (2013) use the MEPI to measure energy poverty in Pakistan based on data from the Pakistan Social and Living Standards Measurement Survey (PSLM) for 2007/08. They find that 54.6 percent of households are energypoor, where the incidence of energy poverty is higher in rural areas than in urban ones.

In measuring energy poverty in Pakistan, this study adapts the MEPI indicators to the availability of data and country-specific characteristics. This yields a wider spatial as well as temporal picture and enables us to make important comparisons by area. The model introduces dimensions of energy that previous studies have not looked at. It also compares energy poverty across the four provinces as well as their rural and urban areas for two periods.

\section{Data and Methodology}

The study uses data from the Pakistan Social and Living Standards Measurement Survey (PSLM) for 2008/09 and 2010/11.2 The survey is conducted by the Pakistan Bureau of Statistics every other year to track Pakistan's performance against poverty alleviation indicators and the MDG targets. The survey is conducted in both rural and urban areas across the four provinces and the capital, Islamabad, using a two-stage stratified sampling technique. Our sample comprises 75,126 households for 2008/09 and 76,546 households for 2010/11. The PSLM's sampling method ensures an appropriate degree of provincial and regional representation.

\footnotetext{
${ }^{2}$ While an analysis going further back may have raised some interesting insights, earlier rounds of the PSLM do not include data for some of the dimensions we have considered.
} 
The energy deprivation index is calculated by gauging the extent of poverty under five headings - cooking, lighting, mobility, services and space temperature regulation - using six indicators (Table 1). The deprivation index measures the extent to which a household is deprived of a certain aspect of energy. The sum of deprivation values for each dimension yields a deprivation count for the household, where a value of 1 means it is deprived of all these dimensions and a value of 0 means it is not deprived of any dimension.

Next, we determine the energy poverty line, assuming that households with a deprivation count below this threshold maintain a minimum standard of living while those with a deprivation count above the threshold are deemed energy-poor. For instance, if a household is deprived of a single dimension, it may not necessarily be energy-poor, but if it is deprived of more than one dimension, then it is likely to have a compromised standard of living. The weight assigned to any one dimension is 0.2 , with a cut-off point of 0.3 - if the deprivation count of a household is less than 0.3 , it is considered nonpoor whereas a count greater than or equal to 0.3 indicates that the household is energy-poor.

Table 1: Construction of deprivation index

\begin{tabular}{|c|c|c|c|c|c|}
\hline \multicolumn{2}{|c|}{ Dimension } & \multicolumn{2}{|c|}{ Indicator } & \multirow{2}{*}{$\begin{array}{c}\text { HIES } \\
\text { questionnaire } \\
\text { section }\end{array}$} & \multirow{2}{*}{$\begin{array}{l}\text { Deprivation criteria } \\
\text { for household }\end{array}$} \\
\hline Type & Weight & Type & Weight & & \\
\hline Cooking & 0.2 & $\begin{array}{l}\text { Modern fuel } \\
\text { for cooking }\end{array}$ & 0.2 & G & $\begin{array}{l}\text { Uses anything other } \\
\text { than modern cooking } \\
\text { fuel (electricity, gas, } \\
\text { kerosene oil) }\end{array}$ \\
\hline Lighting & 0.2 & $\begin{array}{l}\text { Electricity } \\
\text { access }\end{array}$ & 0.2 & G & $\begin{array}{l}\text { Uses anything other } \\
\text { than electricity as } \\
\text { main source of } \\
\text { lighting }\end{array}$ \\
\hline Mobility & 0.2 & $\begin{array}{l}\text { Means of } \\
\text { transportatio } \\
n\end{array}$ & 0.2 & F and $G$ & $\begin{array}{l}\text { Does not own vehicle } \\
\text { The nearest public } \\
\text { transport is more than } \\
14 \text { minutes on foot }\end{array}$ \\
\hline $\begin{array}{l}\text { Space } \\
\text { temperature } \\
\text { regulation }\end{array}$ & 0.2 & Fan & 0.2 & $\mathrm{~F}$ & Does not own a fan \\
\hline \multirow[t]{2}{*}{ Services } & 0.2 & Refrigerator & 0.1 & $\mathrm{~F}$ & $\begin{array}{l}\text { Does not own a } \\
\text { refrigerator }\end{array}$ \\
\hline & & $\mathrm{TV} /$ radio & 0.1 & $\mathrm{~F}$ & $\begin{array}{l}\text { Owns neither a TV } \\
\text { nor radio }\end{array}$ \\
\hline
\end{tabular}

Source: Authors' calculations based on data from the PSLM for 2008/09 and 2010/11. 
The MEPI is defined as the product of the headcount of all energypoor households $(\mathrm{H})$ and the average intensity of poverty (A). Specifically, given a total of $n$ households of which $p$ are found to be energy-poor:

$$
H=\frac{p}{n}
$$

Similarly, if the deprivation count for each household $i$ is $c_{i}$, then A is calculated as follows:

$$
A=\frac{\sum_{i=1}^{n} c_{i}}{p}
$$

Next, we calculate the MEPI:

$$
M E P I=H * A
$$

The value of the MEPI lies between 0 and 1: the higher the score on the index, the greater is the level of deprivation.

It is worth discussing how this study has modified the index used by Nussbaumer et al. (2012). One significant change is the addition of two dimensions of energy use: mobility and space temperature regulation. While the literature acknowledges their importance (see, for example, Sovacool et al., 2012), they are missing from the original index for want of sufficient data. In this case, however, the PSLM provides data on transport means and household ownership of an electric fan, which represent mobility and the ability to regulate space temperature, respectively. This generates a more representative index of energy deprivation for Pakistan. Thus, households that do not own any means of transport (a bicycle, motorcycle or car/truck) and are more than 14 minutes away from the nearest source of public transport are deemed energy-deprived in terms of mobility. Households that own an electric fan would be considered energynonpoor in terms of space temperature regulation. ${ }^{3}$

In addition, Nussbaumer et al. (2012) use two indicators to measure energy use for cooking: modern cooking fuels and indoor pollution (gauged by whether food is cooked on a stove or over an open fire using traditional

\footnotetext{
${ }^{3}$ Originally, the indicator was intended to measure household ownership of either a fan or a heater to take into account areas that were too cold to need fans or too hot to need heaters. However, the PSLM lacks data on the latter, which meant we could not include household ownership of a heater in this study. An analysis of data from the Household Integrated Economic Survey for 2010/11 revealed that only 0.58 percent of households owned a heater but not a fan, making it viable to drop ownership of a heater from the space temperature regulation indicator.
} 
fuels). Our analysis does not include the second indicator: we assume that households that use modern fuels for cooking must own a stove for this purpose. Moreover, there is no data on the kind of stove being used (i.e., whether it has an exhaust and, therefore, causes less indoor pollution).

Nussbaumer et al. (2012) use telecommunication means (a landline or mobile phone) to measure the energy used for communication. We drop this dimension on the grounds that landline telephones do not require energy, making the indicator less relevant. Instead, we use ownership of a television/radio as a proxy for both communication and entertainment, combining this with ownership of a refrigerator to reflect the broad dimension of 'services' provided by energy. Finally, we assume that all five dimensions carry equal weight because they are all essential to maintaining a minimum standard of living. The 'services' dimension is assessed using two equally weighted indicators. ${ }^{4}$

\section{Results and Discussion}

This section presents our results for the level of energy deprivation based on the MEPI.

\subsection{MEPI Scores Across Pakistan}

On a scale of 0 to 1 , the national MEPI for $2010 / 11$ is 0.264 . This shows that each household in Pakistan is, on average, 26.4 percent energydeprived (Figure 1). ${ }^{5}$ Put another way, if maintaining an acceptable standard of living requires 100 percent of the basic energy needs basket, then the average Pakistani household is unable to meet 26.4 percent of its needs. Since this value does not reflect the proportion of energy-poor households, we calculate $\mathrm{H}$, which is equal to 56.2 percent. This implies that more than half the households in Pakistan are energy-poor. When we calculate the energy deprivation level (A) for this proportion, we find that, on average, each energy-poor household falls short of meeting its basic energy needs by 47.1 percent. These findings indicate that more than half the households in Pakistan are energy-poor $(\mathrm{H}=56.2$ percent $)$ and face a very high deprivation level $(\mathrm{A}=47.1$ percent $)$.

\footnotetext{
${ }^{4}$ We do not use principal component analysis to assign weights because it would do so based on the covariance matrix of each variable, intending to make the index more representative of the original data. Our aim, however, is to assign weights to variables according to their importance as a dimension of energy poverty. While this is a more subjective approach, it is also more relevant to the study's aims.

${ }^{5}$ See Table A1 in the Appendix for the tabulated results.
} 


\section{Figure 1: MEPI, energy poverty intensity and headcount}

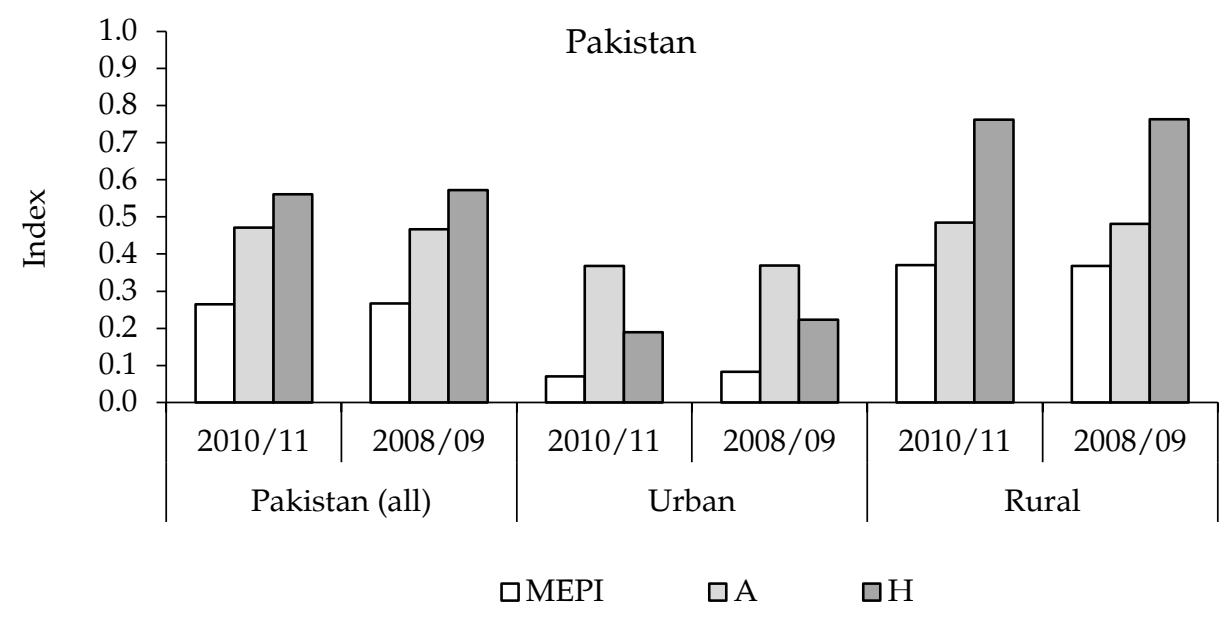

Note: $\mathrm{A}$ = energy deprivation level, $\mathrm{H}=$ proportion of energy-poor households.

Source: Authors' calculations based on data from the PSLM for 2008/09 and 2010/11.

Figure 1 also illustrates the MEPI for rural and urban Pakistan. On average, urban areas fare better, with a MEPI of 7 percent relative to 36.9 percent for rural areas in 2010/11. ${ }^{6}$ The proportion of energy-poor households $(\mathrm{H})$ is 19 percent in urban Pakistan and 76.2 percent in rural Pakistan, with deprivation levels (A) of 36.8 and 48.5 percent, respectively. Overall, not only are a significant number of rural households energy-poor, but they are also unable to benefit from the larger pool of energy-related services available to energy-poor households in urban areas.

\subsection{MEPI Scores by Province}

The deprivation index for the provinces is shown in Figure $2(a-d)$. Overall, Punjab fares best with a MEPI of around 21 percent, followed by Sindh (24.9 percent) and Khyber Pakhtunkhwa (KP) (29 percent). Balochistan has the highest deprivation index at 41.3 percent. The proportion of energy-poor households $(\mathrm{H})$ follows a similar pattern. Balochistan accounts for the largest share of energy-poor households (73.8 percent), followed by KP (60.3 percent). Punjab and Sindh have a far smaller share of energy-poor households: 49.4 percent and 52.6 percent, respectively.

\footnotetext{
${ }^{6}$ The MEPI values we have calculated are not comparable with those in Nussbaumer et al. (2013) because of differences in the methodology employed.
} 
Figure 2: MEPI, energy poverty intensity and headcount, by province

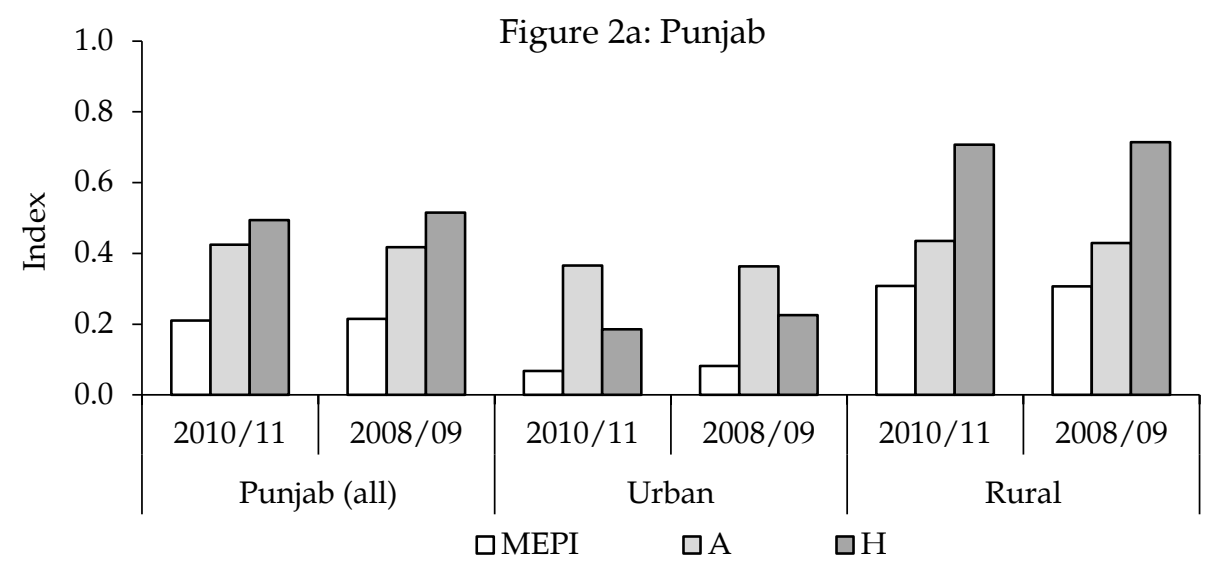

Note: $\mathrm{A}$ = energy deprivation level, $\mathrm{H}$ = proportion of energy-poor households.

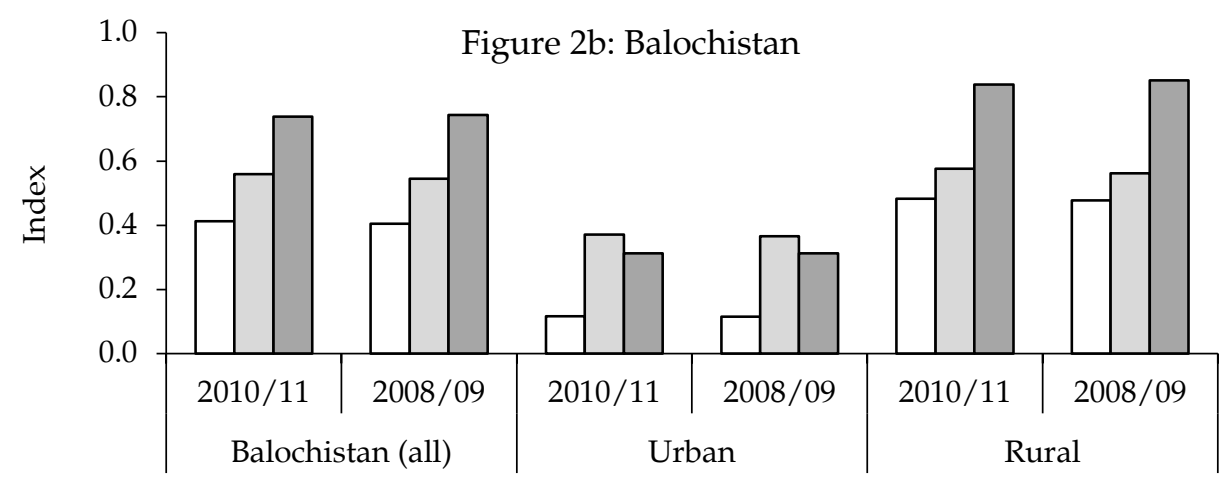

口MEPI $\square \mathrm{A} \quad \square \mathrm{H}$

Note: $\mathrm{A}$ = energy deprivation level, $\mathrm{H}$ = proportion of energy-poor households.

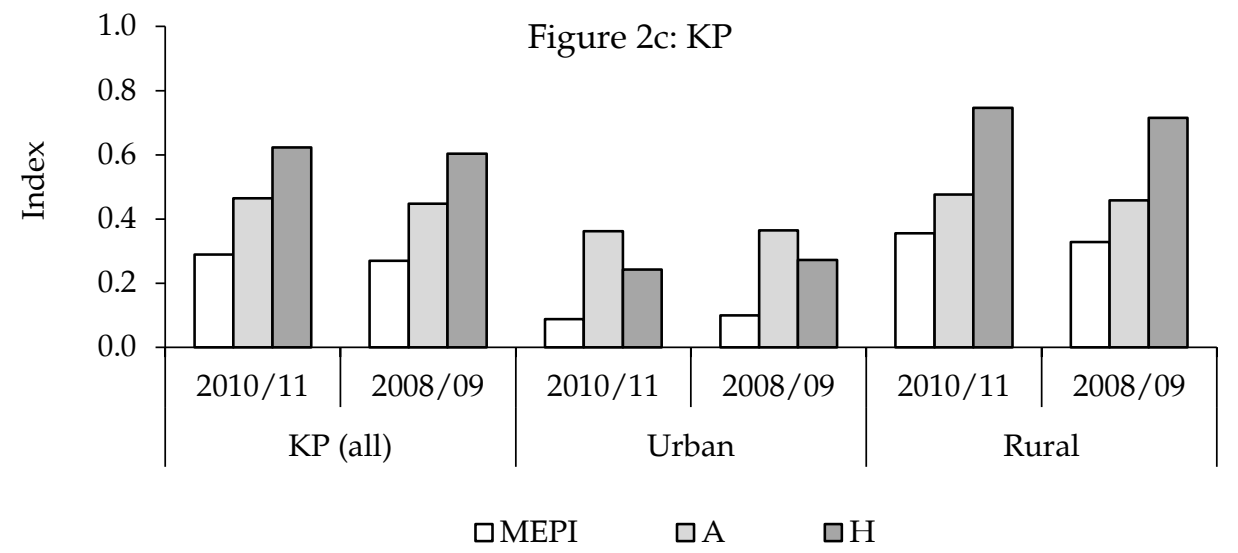

Note: $\mathrm{A}=$ energy deprivation level, $\mathrm{H}=$ proportion of energy-poor households. 


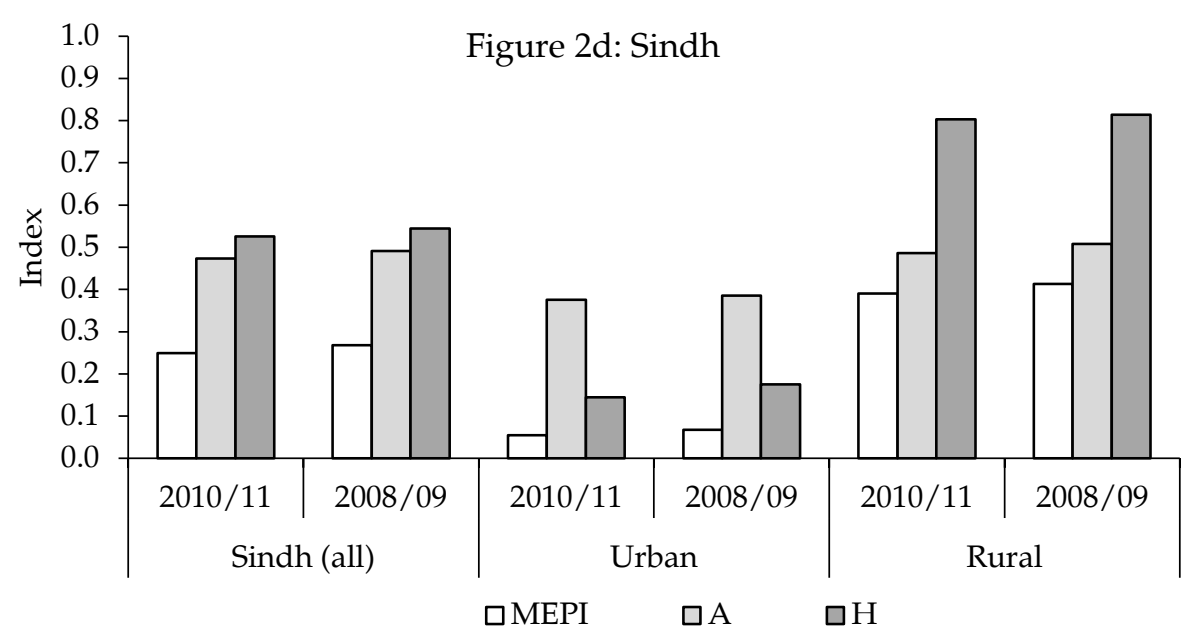

Note: $\mathrm{A}$ = energy deprivation level, $\mathrm{H}$ = proportion of energy-poor households.

Source: Authors' calculations based on data from the PSLM for 2008/09 and 2010/11.

A slightly different pattern emerges when we calculate the deprivation levels (A) for each province. The energy deprivation level of energy-poor households is highest in Balochistan (55.9 percent), followed by Sindh (47.3 percent), KP (46.5 percent) and Punjab (42.5 percent). Thus, while Sindh has fewer energy-poor households than KP, those in Sindh are deprived of more energy-related services than in KP.

Figure 2 also compares MEPI scores across rural and urban areas in each province. Overall, there is a significant rural-urban difference. The proportion of energy-poor households $(\mathrm{H})$ in urban and rural Punjab is 18.5 and 70.7 percent, respectively. The corresponding ratios are 14.4 and 80.3 percent in Sindh, 24.3 and 74.6 percent in KP, and 31.3 and 83.9 percent in Balochistan. The intensity of deprivation (A) in urban Punjab is 36.6 percent relative to 43.5 percent in rural parts of the province. Urban Sindh has a deprivation level of 37.5 percent compared to 48.6 percent in rural Sindh. The corresponding values of A are 36.2 and 47.6 percent for urban and rural $\mathrm{KP}$, and 47.0 and 57.6 percent for urban and rural Balochistan. 


\subsection{Dimensions of Energy Poverty}

Breaking down the index into its five components yields useful insights in terms of their relative importance. Figures $3(a-c)$ and $4(a-1)$ illustrate this for Pakistan and the four provinces. ${ }^{7}$

Figure 3: Distribution of energy-poor households, by energy poverty and urban/rural status

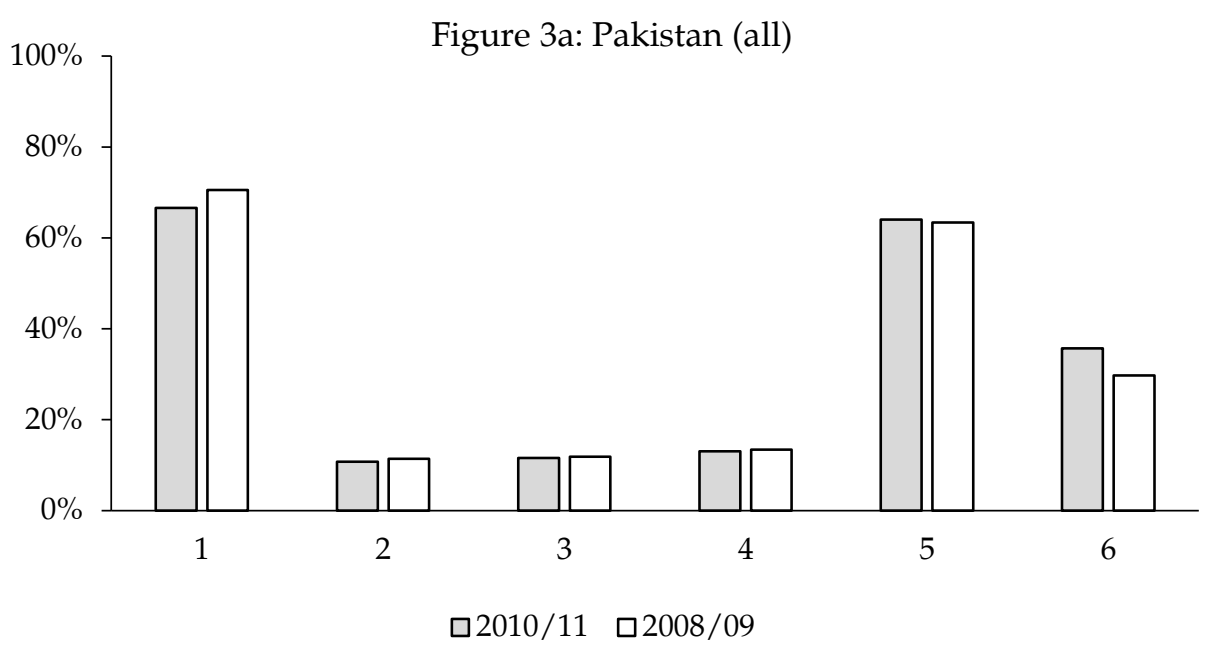

Note: 1 = cooking, 2 = lighting, $3=$ mobility, $4=$ space temperature regulation, $5=$ refrigerator, $6=\mathrm{TV} /$ radio.

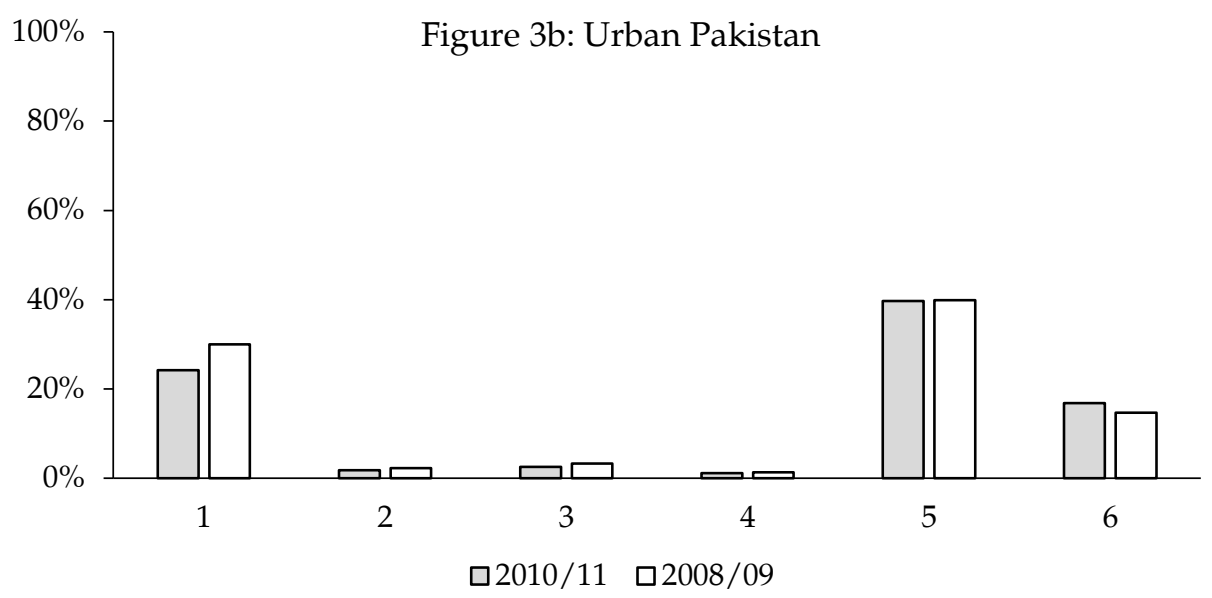

Note: 1 = cooking, 2 = lighting, $3=$ mobility, $4=$ space temperature regulation, $5=$ refrigerator, $6=\mathrm{TV} /$ radio.

${ }^{7}$ See Table A2 in the Appendix for the tabulated results. 


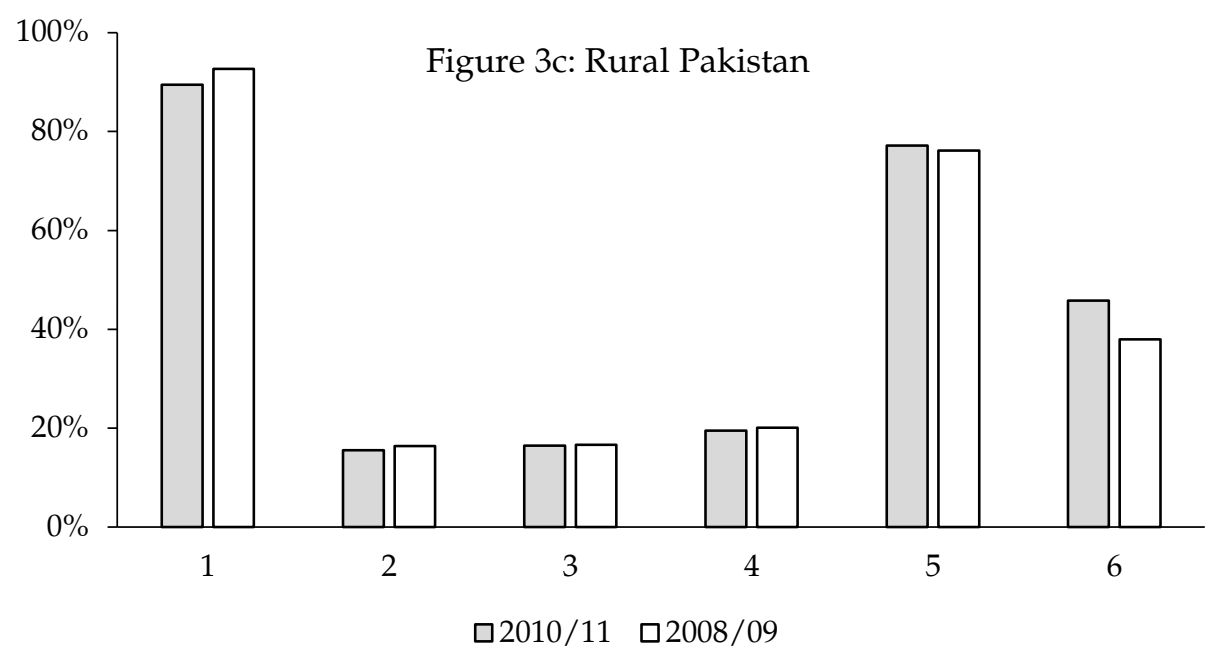

Note: 1 = cooking, 2 = lighting, $3=$ mobility, $4=$ space temperature regulation, $5=$ refrigerator, $6=\mathrm{TV} /$ radio.

Source: Authors' calculations based on data from the PSLM for 2008/09 and 2010/11.

Figure 4: Distribution of energy-poor households, by energy poverty, province and urban/rural status

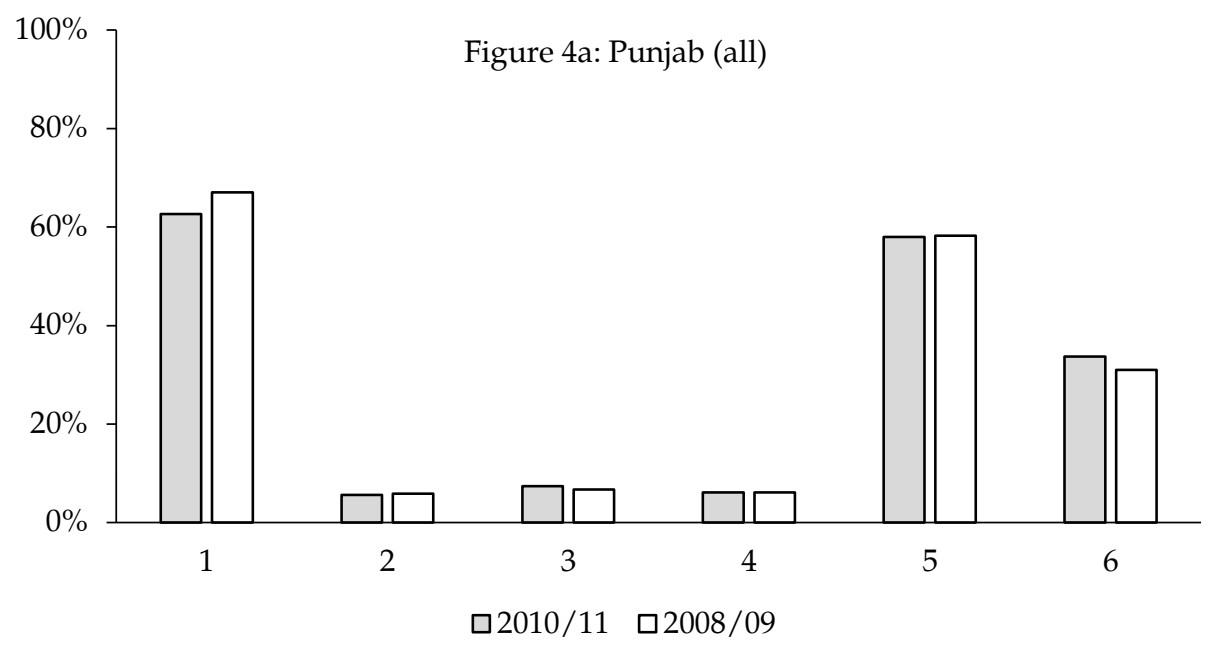

Note: $1=$ cooking, 2 = lighting, $3=$ mobility, $4=$ space temperature regulation, $5=$ refrigerator, $6=\mathrm{TV} /$ radio. 


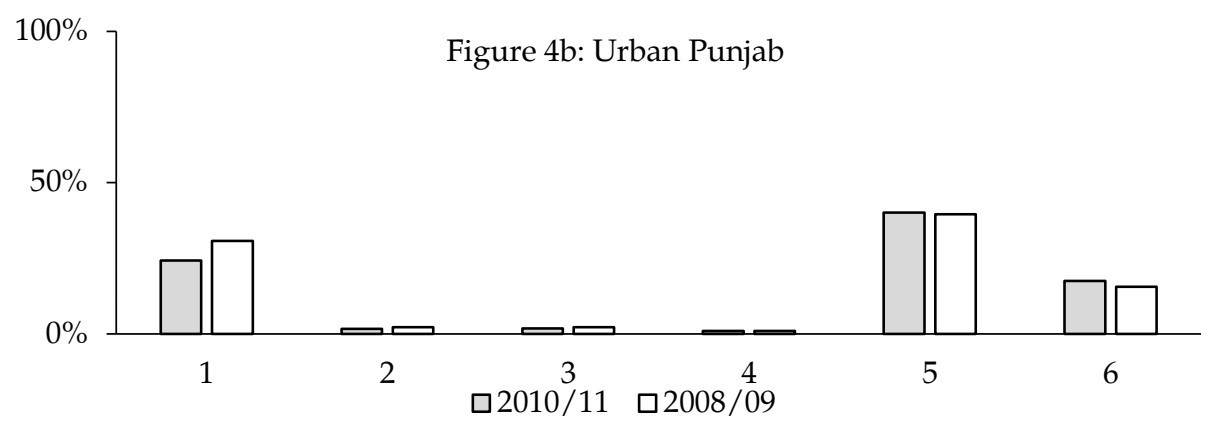

Note: $1=$ cooking, $2=$ lighting, $3=$ mobility, $4=$ space temperature regulation, $5=$ refrigerator, $6=\mathrm{TV} /$ radio.

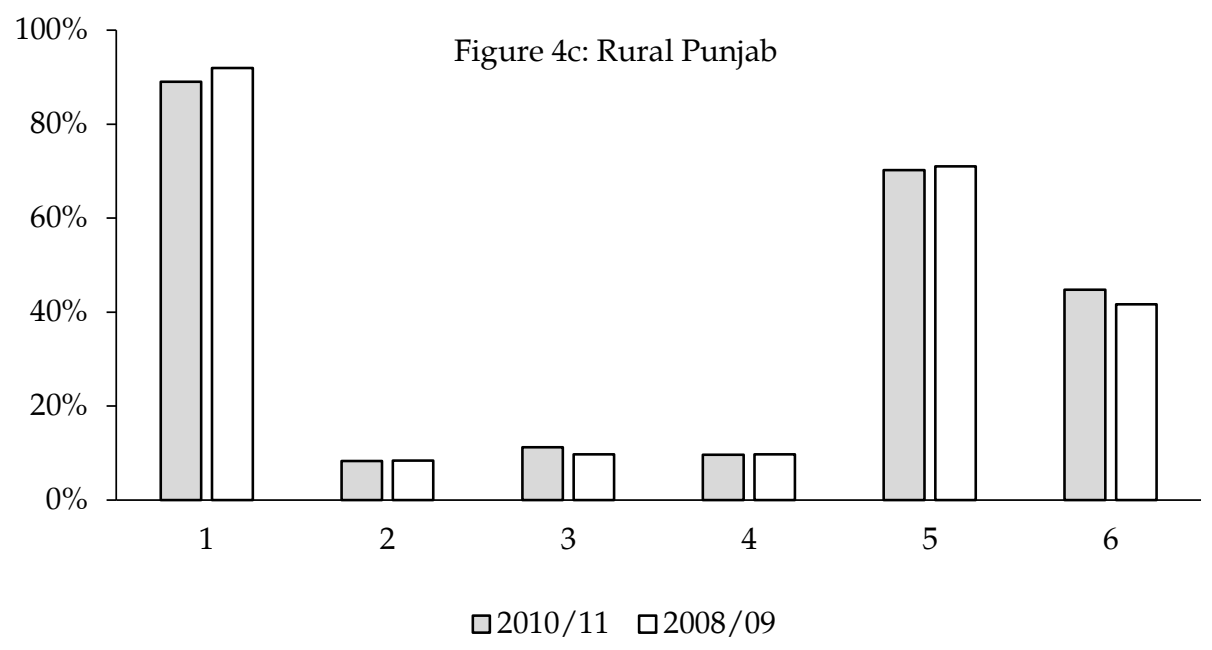

Note: 1 = cooking, 2 = lighting, $3=$ mobility, $4=$ space temperature regulation, $5=$ refrigerator, $6=\mathrm{TV} /$ radio.

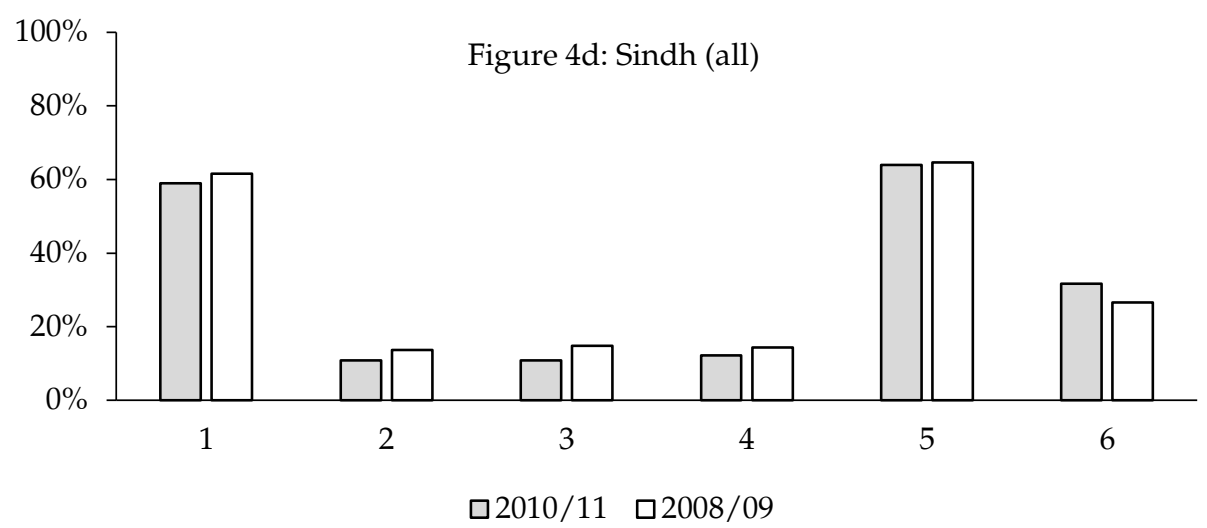

Note: 1 = cooking, 2 = lighting, $3=$ mobility, $4=$ space temperature regulation, $5=$ refrigerator, $6=\mathrm{TV} /$ radio. 


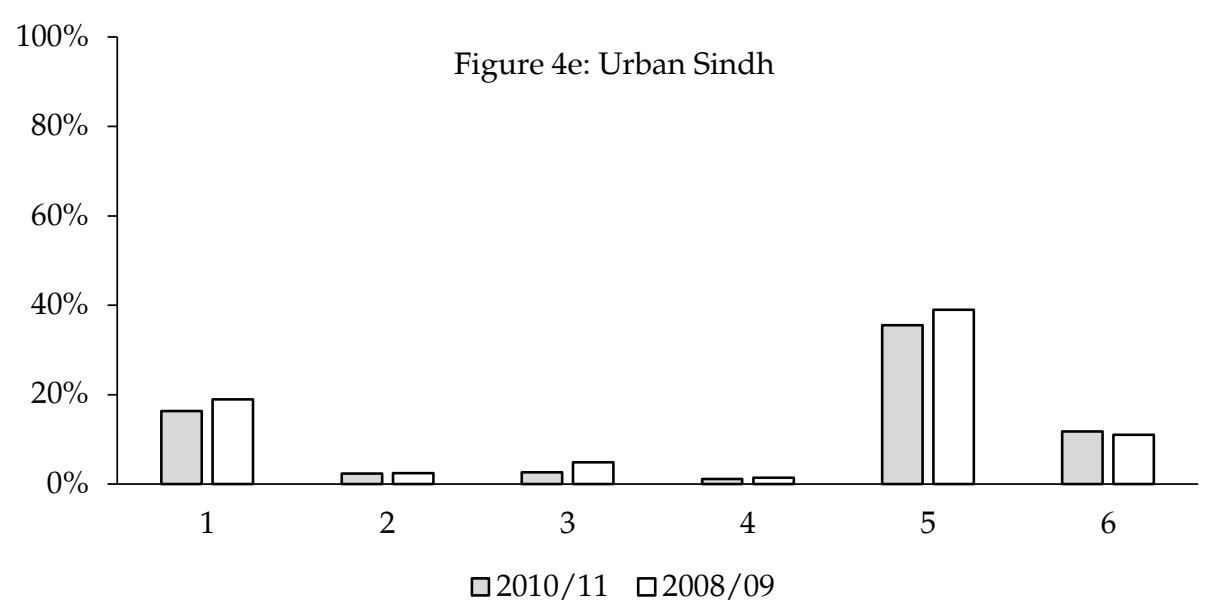

Note: 1 = cooking, 2 = lighting, $3=$ mobility, 4 = space temperature regulation, $5=$ refrigerator, $6=\mathrm{TV} /$ radio.

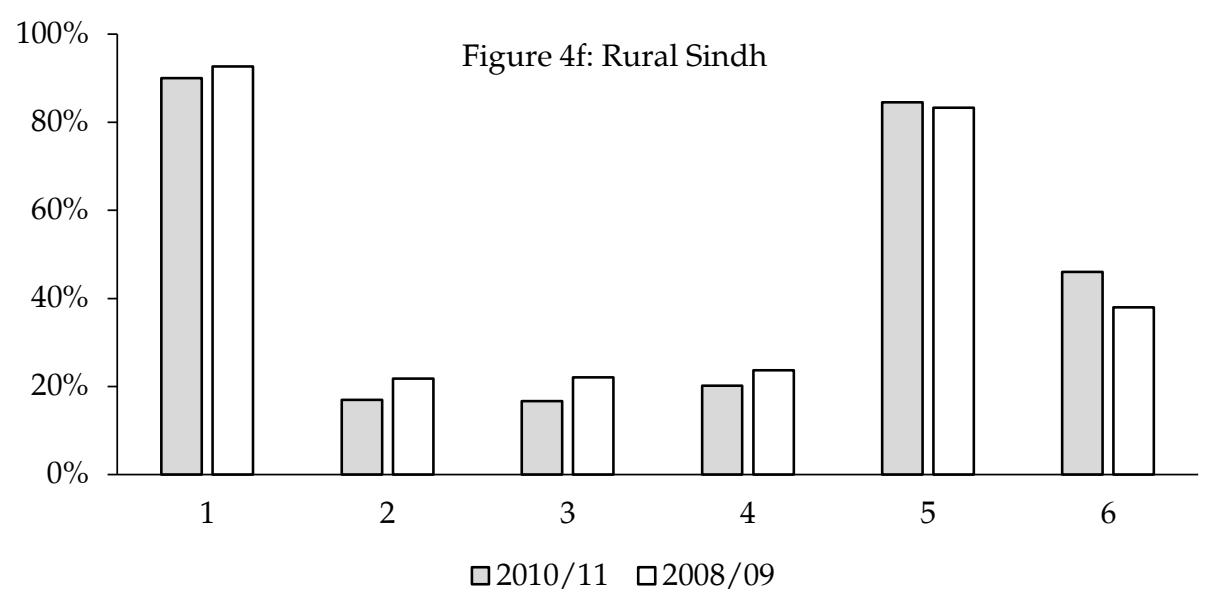

Note: 1 = cooking, 2 = lighting, $3=$ mobility, $4=$ space temperature regulation, $5=$ refrigerator, $6=\mathrm{TV} /$ radio. 


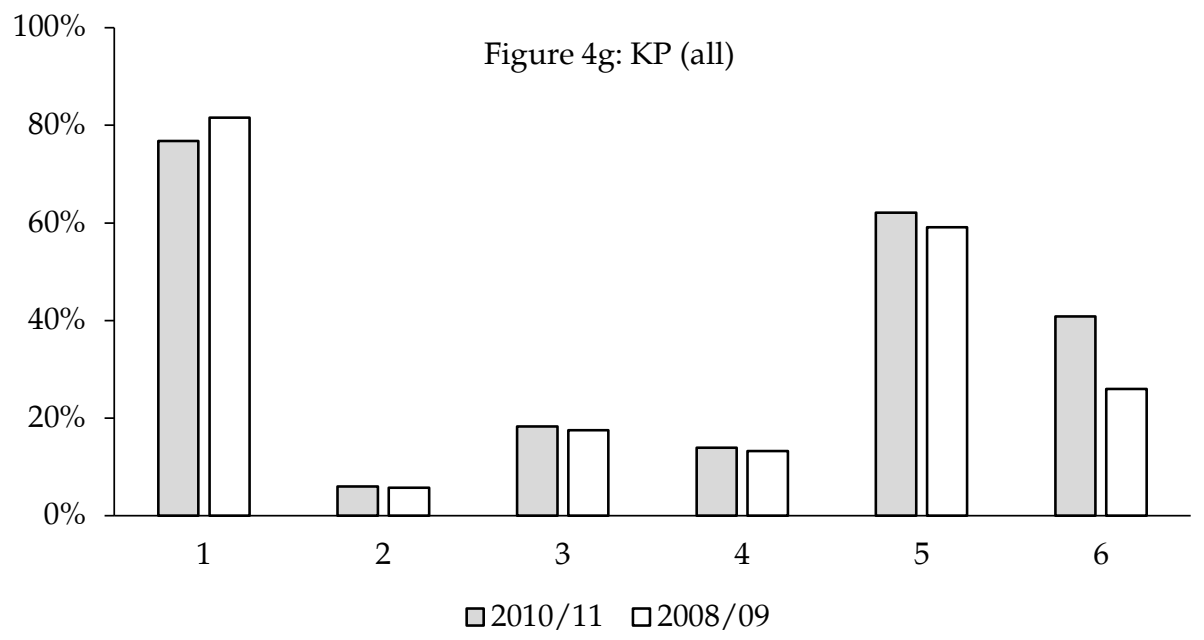

Note: 1 = cooking, 2 = lighting, $3=$ mobility, $4=$ space temperature regulation, $5=$ refrigerator, $6=\mathrm{TV} /$ radio.

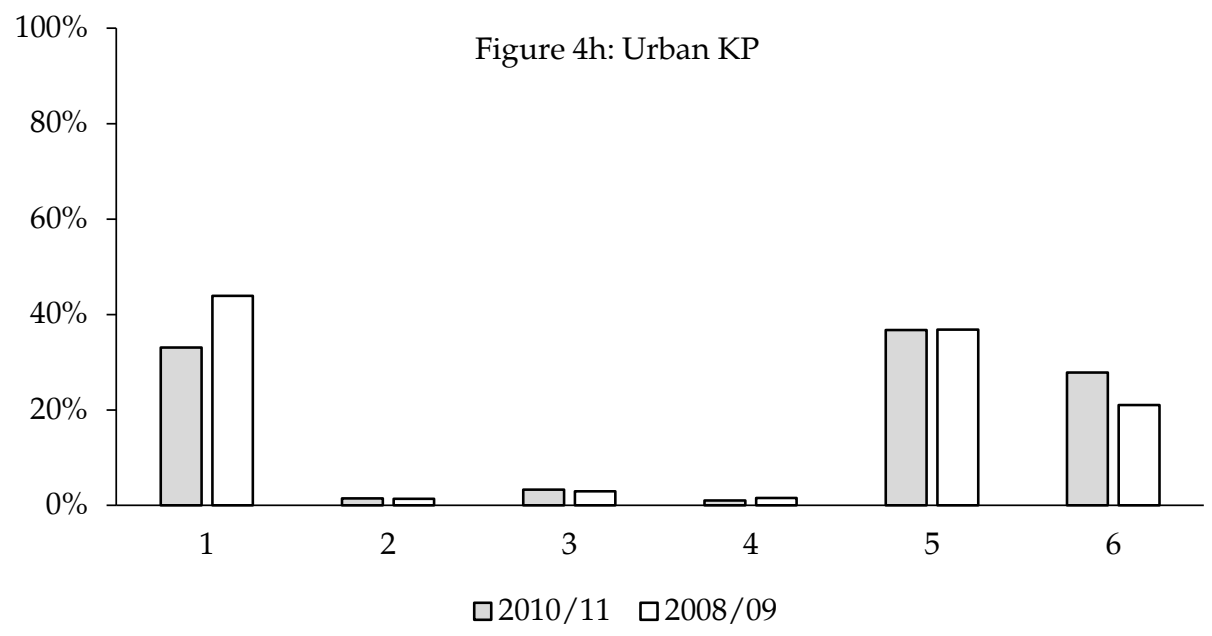

Note: 1 = cooking, 2 = lighting, $3=$ mobility, $4=$ space temperature regulation, $5=$ refrigerator, $6=\mathrm{TV} /$ radio. 


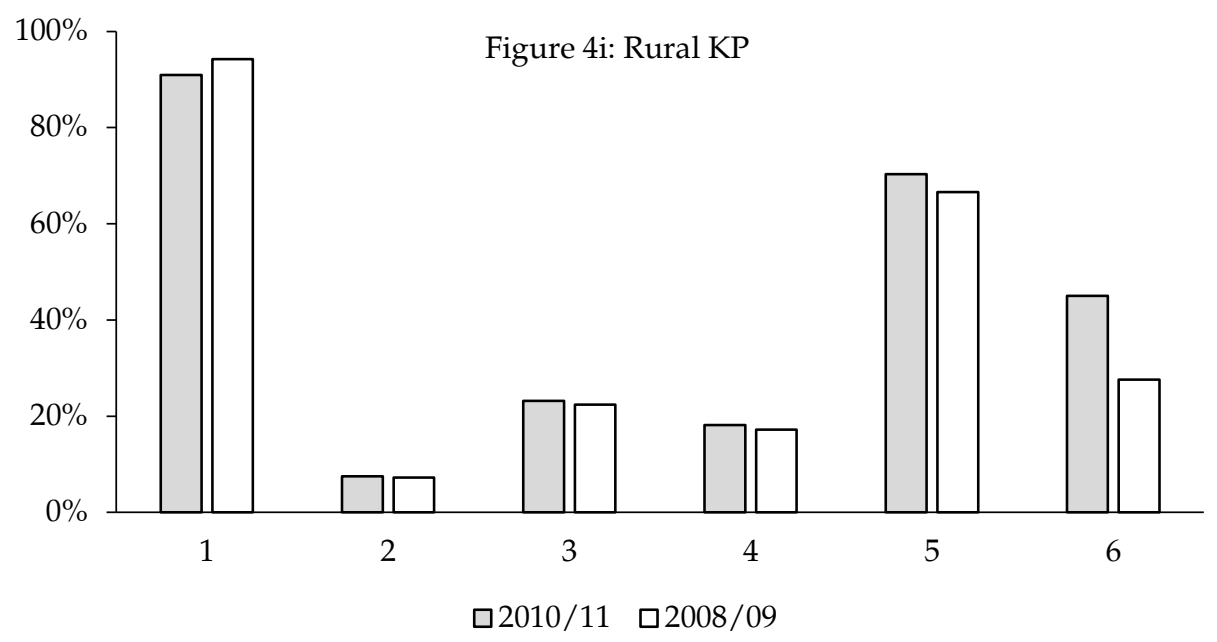

Note: 1 = cooking, 2 = lighting, $3=$ mobility, $4=$ space temperature regulation, $5=$ refrigerator, $6=\mathrm{TV} /$ radio.

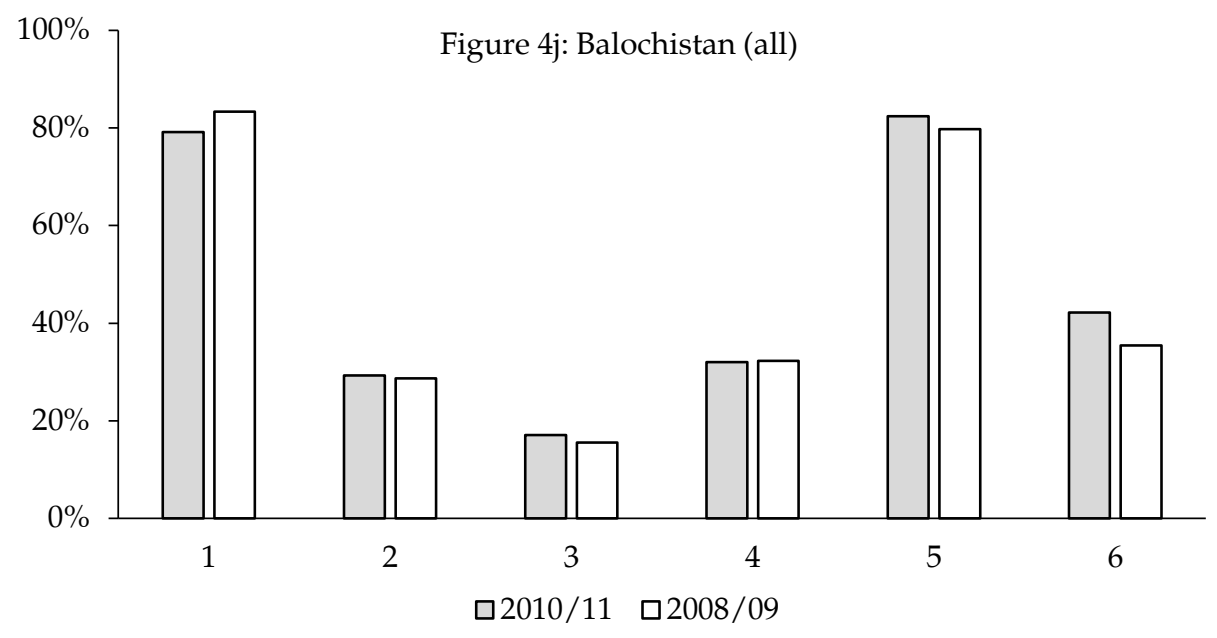

Note: 1 = cooking, 2 = lighting, $3=$ mobility, $4=$ space temperature regulation, $5=$ refrigerator, $6=\mathrm{TV} /$ radio. 


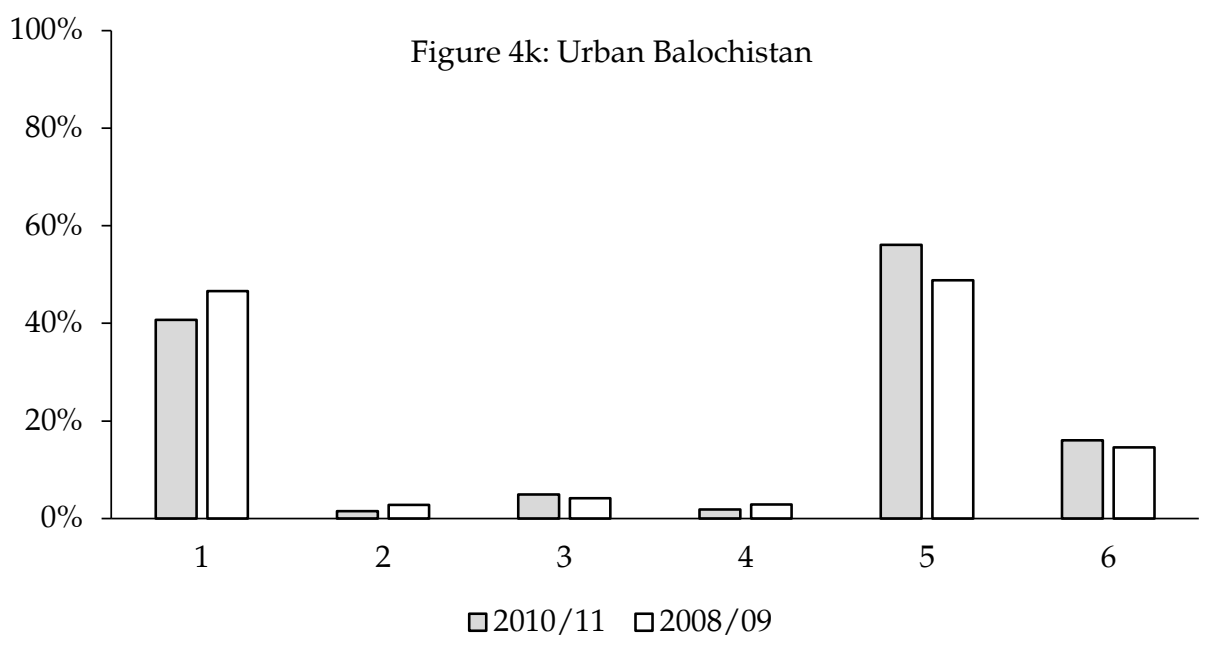

Note: 1 = cooking, 2 = lighting, $3=$ mobility, $4=$ space temperature regulation, $5=$ refrigerator, $6=\mathrm{TV} /$ radio.

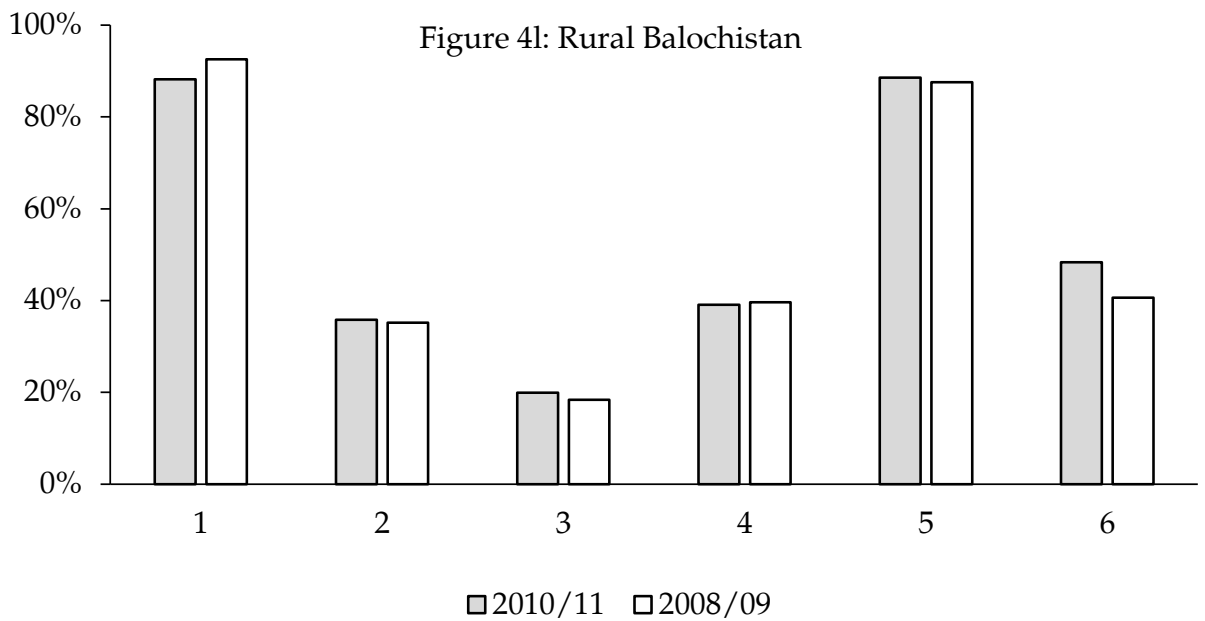

Note: 1 = cooking, 2 = lighting, $3=$ mobility, 4 = space temperature regulation, $5=$ refrigerator, $6=\mathrm{TV} /$ radio.

Source: Authors' calculations based on data from the PSLM for 2008/09 and 2010/11.

The lack of modern cooking fuels accounts for the largest share of energy poverty at the household level: around 67 percent of households in Pakistan report using traditional fuels to cook. The use of modern fuels in rural areas is very low, with 91 percent of households relying on traditional fuels in rural KP. The use of energy for lighting yields a better picture: the percentage of deprived households remains in single digits except for rural Sindh and Balochistan where it is 17 and 36 percent, respectively. 
Although the percentage of households that own an electric fan is closely related to the proportion using electricity as their main source of lighting, we observe a different trend in rural areas: many households that own an electric fan report using gas or kerosene as their main source of lighting instead. This could be explained by the relative cost factor, where households restrict their use of electricity to meeting only those energy needs that cannot be met otherwise. ${ }^{8}$

The mobility dimension of the MEPI is more prominent in rural areas, particularly in rural KP and Balochistan. With respect to the services and entertainment dimension, our findings show that around 64 percent of households do not own a refrigerator while 36 percent lack a TV/radio, reflecting lower use of electricity.

\subsection{Comparison of MEPI, 2008/09 and 2010/11}

Figures 1-4 suggest that, on average, energy use has improved slightly at the national level between 2008/09 and 2010/11. Although the overall MEPI and proportion of energy-poor households $(\mathrm{H})$ has declined across rural Pakistan, the intensity of deprivation (A) for these households has risen slightly over this period. Thus, it has become more difficult for energy-poor households to meet their energy needs over time.

The level of energy deprivation in terms of cooking fuels has a small downward trend across Pakistan from 2008/09 to 2010/11. Overall, rural areas reflect greater deterioration in terms of energy use (barring rural Sindh), but even urban Balochistan has fared badly. This poorer performance over time also emerges across the services dimension, while households in rural Punjab and in both urban and rural Balochistan face higher levels of deprivation in terms of energy for mobility. Finally, rural $\mathrm{KP}$ and Balochistan have both witnessed a fall in access to electricity for lighting, so that most rural households tend to rely on other sources to meet their lighting needs.

\section{Conclusion}

Given the upward trend in energy poverty in Pakistan, this study analyzes the provision of energy at the household level, using a comprehensive, country-specific index adapted from Nussbaumer et al.

\footnotetext{
${ }^{8}$ The problem of energy poverty tends to be aggravated by income poverty. We find that the lower income quintiles account for a higher percentage of energy-poor households. However, even the highest income quintile features energy poverty, which highlights the difference between the two concepts.
} 
(2012). We focus on deprivation rather than access to energy in estimating energy poverty at the national and provincial levels for 2010/11 and 2008/09. The energy poverty index we have adapted measures five dimensions of energy that are deemed essential to a baseline standard of living. These include cooking, lighting, mobility, space temperature regulation and services provided by energy.

The study finds that energy poverty fell slightly between 2008/09 and 2010/11, with the MEPI declining slightly to 0.265 from 0.267 . Our findings show that rural areas tend to face higher levels of energy deprivation than urban areas. It is worth mentioning that our calculations do not take into account scheduled power outages, which affect the use of electricity-powered amenities. This factor is likely to have produced underestimates of the MEPI for the country in general and for rural areas in particular, which were subject to long periods of electricity outages during both survey rounds.

Our results call for steps to improve the availability of energy in Pakistan, particularly the provision of modern cooking fuels and energy for lighting and transport. This implies that the government should ensure that projects designed to deliver electricity and related services are completed on time. Moreover, rural areas and the province of Balochistan, which face higher levels of deprivation, need special attention in this context. The China-Pakistan Economic Corridor project represents a significant opportunity in this respect, giving Pakistan the chance to initiate new energy projects in less developed areas of the country.

Future avenues of research include developing a richer set of representative indicators for each dimension and adding new dimensions depending on the data available. This would help refine measures of energy poverty for Pakistan and allow comparisons with other South Asian countries as well as the rest of the world. 


\section{References}

Awan, R., Sher, F., \& Abbas, A. (2013, December). An investigation of multidimensional energy poverty in Pakistan. Paper presented at the 29th AGM of the Pakistan Society of Development Economists, Islamabad.

Barnes, D. F., Khandker, S. R., \& Samad, H. A. (2011). Energy poverty in rural Bangladesh. Energy Policy, 39(2), 894-904.

Bravo, V., Mendoza, G. G., Legisa, J., Suárez, C. E., \& Zyngierman, I. (1983). A first approach to defining basic energy needs. Tokyo: United Nations University.

Department for International Development. (2002). Energy for the poor: Underpinning the Millennium Development Goals. London: Author.

Fitzgerald, K. B., Barnes, D., \& McGranahan, G. (1990). Interfuel substitution and changes in the way households use energy: The case of cooking and lighting behavior in urban Java (Industry and Energy Department Working Paper No. 29). Washington, DC: World Bank.

Foster, V., Tre, J.-P., \& Wodon, Q. (2000). Energy prices, energy efficiency and fuel poverty. Unpublished manuscript, World Bank, Latin American and Caribbean Regional Studies Program, Washington, DC.

Goldemberg, J., \& Johansson, T. B. (1995). Overview: Energy as an instrument for socioeconomic development. In T. B. Johansson \& J. Goldemberg (Eds.), Energy as an instrument for socioeconomic development (pp. 9-17). New York: United Nations Development Programme.

Hu, Z., \& Hu, Z. (2013). Electricity economics: Production functions with electricity. Berlin: Springer-Verlag.

International Atomic Energy Agency. (2005). Energy indicators for sustainable development: Guidelines and methodologies. Vienna: Author.

Leach, G., \& Mearns, R. (1988). Beyond the wood fuel crisis: People, land and trees in Africa. London: Earthscan.

Mirza, B., \& Szirmai, A. (2010). Towards a new measurement of energy poverty: A cross-community analysis of rural Pakistan (UNU-MERIT Working Paper No. 24). Maastricht: Maastricht Economic and Social Research and Training Centre on Innovation and Technology. 
Munasinghe, M. (1992, June). Environmental economics and sustainable development. Paper presented at the UN Earth Summit, Rio de Janeiro.

Nussbaumer, P., Bazilian, M., \& Modi, V. (2012). Measuring energy poverty: Focusing on what matters. Renewable and Sustainable Energy Reviews, 16(1), 231-243.

Nussbaumer, P., Nerini, F. F., Onyeji, I., \& Howells, M. (2013). Global insights based on the multidimensional energy poverty index (MEPI). Sustainability, 5(5), 2060-2076.

Pachauri, S., Mueller, A., Kemmler, A., \& Spreng, D. (2004). On measuring energy poverty in Indian households. World Development, 32(12), 2083-2104.

Pachauri, S., \& Spreng, D. (2004). Energy use and energy access in relation to poverty. Economic and Political Weekly, 39(3), 271-278.

Sarin, M. (1991). Improved stoves, women and domestic energy. Environment and Urbanization, 3(2), 51-56.

Schultz, T. P. (1990). Returns to women's education (Economic Growth Center Discussion Paper No. 603). New Haven, CT: Yale University Press.

Smith, K. R., Mehta, S., \& Maeusezahl-Feuz, M. (2004). Indoor air pollution from household use of solid fuels. In M. Ezzati, A. D. Lopez, A. Rodgers \& C. J. L. Murray (Eds.), Comparative quantification of health risks: Global and regional burden of disease attributable to selected major risk factors (chap. 18). Geneva: World Health Organization.

Sovacool, B. K., Cooper, C., Bazilion, M., Johnson, K., ... Raza, H. A. (2012). What moves and works: Broadening the consideration of energy poverty. Energy Policy, 42, 715-719.

United Nations Development Programme. (2000). World energy assessment: Energy and the challenge of sustainability. New York: Author.

United Nations Millennium Project. (2005). Investing in development: A practical plan to achieve the Millennium Development Goals. New York: UNDP. 
van der Klaauw, B., \& Wang, L. (2003). Child mortality in rural India: Determinants and policy implications. Unpublished manuscript, World Bank, Washington, DC.

World Bank. (2002). ESMAP business plan, 2002-2004. Washington, DC: Author.

World Commission on Environment and Development. (1987). Our common future. New York: Oxford University Press. 


\section{Appendix}

Table A1: MEPI scores for Pakistan, by province and region

\begin{tabular}{|c|c|c|c|c|}
\hline Country/province & Year & $\mathbf{H}$ & A & MEPI \\
\hline \multirow[t]{2}{*}{ Pakistan } & $2010 / 11$ & 0.562 & 0.471 & 0.264 \\
\hline & 2008/09 & 0.572 & 0.466 & 0.267 \\
\hline \multirow[t]{2}{*}{ Pakistan (urban) } & $2010 / 11$ & 0.190 & 0.368 & 0.070 \\
\hline & 2008/09 & 0.223 & 0.369 & 0.082 \\
\hline \multirow[t]{2}{*}{ Pakistan (rural) } & $2010 / 11$ & 0.762 & 0.485 & 0.370 \\
\hline & 2008/09 & 0.764 & 0.482 & 0.368 \\
\hline \multirow[t]{2}{*}{ Punjab } & $2010 / 11$ & 0.494 & 0.425 & 0.210 \\
\hline & 2008/09 & 0.515 & 0.418 & 0.215 \\
\hline \multirow[t]{2}{*}{ Punjab (urban) } & $2010 / 11$ & 0.185 & 0.366 & 0.068 \\
\hline & $2008 / 09$ & 0.225 & 0.363 & 0.082 \\
\hline \multirow[t]{2}{*}{ Punjab (rural) } & $2010 / 11$ & 0.707 & 0.435 & 0.308 \\
\hline & 2008/09 & 0.715 & 0.430 & 0.307 \\
\hline \multirow[t]{2}{*}{ Sindh } & $2010 / 11$ & 0.526 & 0.473 & 0.249 \\
\hline & 2008/09 & 0.544 & 0.491 & 0.267 \\
\hline \multirow[t]{2}{*}{ Sindh (urban) } & $2010 / 11$ & 0.144 & 0.375 & 0.054 \\
\hline & 2008/09 & 0.175 & 0.385 & 0.067 \\
\hline \multirow[t]{2}{*}{ Sindh (rural) } & $2010 / 11$ & 0.803 & 0.486 & 0.390 \\
\hline & 2008/09 & 0.814 & 0.508 & 0.413 \\
\hline \multirow[t]{2}{*}{$\mathrm{KP}$} & $2010 / 11$ & 0.623 & 0.465 & 0.290 \\
\hline & 2008/09 & 0.603 & 0.448 & 0.270 \\
\hline \multirow[t]{2}{*}{ KP (urban) } & $2010 / 11$ & 0.243 & 0.362 & 0.088 \\
\hline & 2008/09 & 0.273 & 0.364 & 0.099 \\
\hline \multirow[t]{2}{*}{ KP (rural) } & $2010 / 11$ & 0.746 & 0.476 & 0.355 \\
\hline & 2008/09 & 0.715 & 0.458 & 0.328 \\
\hline \multirow[t]{2}{*}{ Balochistan } & $2010 / 11$ & 0.738 & 0.559 & 0.413 \\
\hline & 2008/09 & 0.743 & 0.545 & 0.405 \\
\hline \multirow[t]{2}{*}{ Balochistan (urban) } & $2010 / 11$ & 0.313 & 0.370 & 0.116 \\
\hline & 2008/09 & 0.313 & 0.366 & 0.115 \\
\hline \multirow[t]{2}{*}{ Balochistan (rural) } & $2010 / 11$ & 0.839 & 0.576 & 0.483 \\
\hline & 2008/09 & 0.851 & 0.561 & 0.478 \\
\hline
\end{tabular}

Source: Authors' calculations based on data from the PSLM for 2008/09 and 2010/11. 
Table A2: Percentage of poor households, by energy poverty and province

\begin{tabular}{|c|c|c|c|c|c|c|c|}
\hline $\begin{array}{l}\text { Country / } \\
\text { province }\end{array}$ & Year & 1 & 2 & 3 & 4 & 5 & 6 \\
\hline \multirow[t]{2}{*}{ Pakistan } & $2010 / 11$ & 0.890 & 0.083 & 0.112 & 0.097 & 0.702 & 0.448 \\
\hline & $2008 / 09$ & 0.920 & 0.084 & 0.097 & 0.097 & 0.710 & 0.416 \\
\hline \multirow[t]{2}{*}{ Urban } & $2010 / 11$ & 0.590 & 0.108 & 0.108 & 0.122 & 0.639 & 0.316 \\
\hline & $2008 / 09$ & 0.616 & 0.136 & 0.148 & 0.143 & 0.646 & 0.266 \\
\hline \multirow[t]{2}{*}{ Rural } & $2010 / 11$ & 0.163 & 0.023 & 0.026 & 0.011 & 0.355 & 0.118 \\
\hline & $2008 / 09$ & 0.189 & 0.024 & 0.049 & 0.014 & 0.390 & 0.110 \\
\hline \multirow[t]{2}{*}{ Punjab } & $2010 / 11$ & 0.900 & 0.170 & 0.167 & 0.202 & 0.846 & 0.460 \\
\hline & $2008 / 09$ & 0.927 & 0.218 & 0.221 & 0.237 & 0.833 & 0.380 \\
\hline \multirow[t]{2}{*}{ Urban } & $2010 / 11$ & 0.768 & 0.060 & 0.183 & 0.140 & 0.621 & 0.408 \\
\hline & $2008 / 09$ & 0.816 & 0.057 & 0.175 & 0.133 & 0.591 & 0.259 \\
\hline \multirow[t]{2}{*}{ Rural } & $2010 / 11$ & 0.330 & 0.015 & 0.033 & 0.010 & 0.367 & 0.278 \\
\hline & $2008 / 09$ & 0.439 & 0.014 & 0.030 & 0.015 & 0.368 & 0.210 \\
\hline \multirow[t]{2}{*}{ Sindh } & $2010 / 11$ & 0.910 & 0.075 & 0.232 & 0.182 & 0.704 & 0.450 \\
\hline & $2008 / 09$ & 0.942 & 0.072 & 0.224 & 0.172 & 0.666 & 0.276 \\
\hline \multirow[t]{2}{*}{ Urban } & $2010 / 11$ & 0.791 & 0.293 & 0.171 & 0.320 & 0.824 & 0.422 \\
\hline & $2008 / 09$ & 0.833 & 0.287 & 0.155 & 0.323 & 0.798 & 0.354 \\
\hline \multirow[t]{2}{*}{ Rural } & $2010 / 11$ & 0.407 & 0.015 & 0.049 & 0.018 & 0.561 & 0.160 \\
\hline & $2008 / 09$ & 0.466 & 0.028 & 0.042 & 0.029 & 0.488 & 0.146 \\
\hline \multirow[t]{2}{*}{$\mathrm{KP}$} & $2010 / 11$ & 0.882 & 0.358 & 0.200 & 0.391 & 0.886 & 0.484 \\
\hline & $2008 / 09$ & 0.925 & 0.352 & 0.184 & 0.397 & 0.875 & 0.406 \\
\hline \multirow[t]{2}{*}{ Urban } & $2010 / 11$ & 0.890 & 0.083 & 0.112 & 0.097 & 0.702 & 0.448 \\
\hline & $2008 / 09$ & 0.920 & 0.084 & 0.097 & 0.097 & 0.710 & 0.416 \\
\hline \multirow[t]{2}{*}{ Rural } & $2010 / 11$ & 0.590 & 0.108 & 0.108 & 0.122 & 0.639 & 0.316 \\
\hline & $2008 / 09$ & 0.616 & 0.136 & 0.148 & 0.143 & 0.646 & 0.266 \\
\hline \multirow[t]{2}{*}{ Balochistan } & $2010 / 11$ & 0.163 & 0.023 & 0.026 & 0.011 & 0.355 & 0.118 \\
\hline & $2008 / 09$ & 0.189 & 0.024 & 0.049 & 0.014 & 0.390 & 0.110 \\
\hline \multirow[t]{2}{*}{ Urban } & $2010 / 11$ & 0.900 & 0.170 & 0.167 & 0.202 & 0.846 & 0.460 \\
\hline & $2008 / 09$ & 0.927 & 0.218 & 0.221 & 0.237 & 0.833 & 0.380 \\
\hline \multirow[t]{2}{*}{ Rural } & $2010 / 11$ & 0.768 & 0.060 & 0.183 & 0.140 & 0.621 & 0.408 \\
\hline & $2008 / 09$ & 0.816 & 0.057 & 0.175 & 0.133 & 0.591 & 0.259 \\
\hline
\end{tabular}

Source: Authors' calculations based on data from the PSLM for 2008/09 and 2010/11. 